\title{
EFEKTIVITAS PEMBERIAN AIR CUCIAN BERAS TERHADAP PERTUMBUHAN DAN PRODUKSI SELEDRI (Apium graveolens L.)
}

\author{
Junaidi Pangeran Saputra ${ }^{1}$ \\ ${ }^{1}$ BPTP Kaltim, Jl. P.M. Noor, Sempaja Selatan, Kecamatan Samarinda Utara, \\ Kota Samarinda, Kalimantan Timur 75119 \\ E-Mail: atankbiyik@yahoo.co.id
}

\begin{abstract}
ABSTRAK
Efektivitas Pemberian Air Cucian Beras Terhadap Pertumbuhan Dan Produksi Seledri (Apium graveolens $\mathbf{L}$.). Air cucian beras sering dibuang dan dianggap limbah rumah tangga padahal air cucian beras dapat dimanfaatkan dan memiliki potensi sebagai pupuk organik cair pada tanaman untuk mengurangi penggunaan pupuk kimia yang berlebihan. Tujuan penelitian untuk mendapatkan efektivitas pemberian air cucian beras dan gula yang diperbanyak dengan air bersih terhadap pertumbuhan dan produksi tanaman seledri. Metode menggunakan RAL satu faktor; 4 perlakuan dan 4 ulangan, tiap ulangan terdapat 4 polybag sampel tanaman. Perlakuan A; 1 liter air cucian beras +1 liter air bersih, B; 1 liter air cucian beras +1 liter air bersih, C; 1 liter air cucian beras beras +1 liter air bersih +2 gr gula pasir, D; 1 liter air cucian beras +2 liter air bersih +2 gr gula pasir. Pengambilan data umur 6 MST dan parameter diamati: tinggi tanaman $(\mathrm{cm})$, jumlah daun (helai), jumlah batang (helai), bobot segar brangkasan tanaman (gr) dan bobot segar tanaman (gr). Data hasil pengamatan dianalisis one-way MANOVA dan dilanjutkan Tukey. Hasil penelitian efektivitas pemberian air cucian beras dan gula berbeda nyata pada perlakuan A, B, C dan D terhadap jumlah batang tanaman tetapi tidak berbeda nyata pada tinggi tanaman, jumlah daun, bobot segar brangkasan dan bobot segar tanaman. Perlakuan A lebih efektif pada tinggi tanaman $(23 \mathrm{~cm})$, bobot segar brangkasan $(7,31 \mathrm{gr})$ dan bobot segar tanaman (6,38 gr). Perlakuan C lebih efektif pada jumlah daun (31,63 helai) dan jumlah batang (7,31 helai).
\end{abstract}

Kata kunci : Air cucian beras, Apium Graveolens L, Efektivitas, Pupuk organik cair

\section{ABSTRACT}

The Effectiveness of The Washing Water of Rice on The Growth and Production of Celery (Apium graveolens L.). The washing water of rice are often thrown away and considered household waste when the washing water of rice can be used and has the potential as liquid organic fertilizer on plants to reduce the excessive use of chemical fertilizers. The purpose of the study to obtain the effectiveness of the provision of rice and sugar washing water hat is reproduced with clean water to the growth and production of celery plants. The method of using RAL is one factor; 4 treatments and 4 replications, each test there are 4 polybags of plant samples. Treatment A; 1 liter of water washing rice +1 liter of clean water, B; 1 liter of water washing rice +1 liter of clean water, $C$; 1 liter of water washing rice +1 liter of clean water +2 gr of granulated sugar, D; 1 liter of water washing rice +2 liters of clean water +2 gr of granulated sugar. Data collection age 6 MST and parameters observed: plant height (cm), number of leaves (strands), number of stems (strands), ), fresh weight of plant stover ( $\mathrm{gr}$ ), and fresh weight of plants ( $\mathrm{gr}$ ). The observation data were analyzed one-way MANOVA and continued Tukey. The results of the study on the effectiveness of the administration of rice and sugar washing water differed markedly on the treatment of $A, B, C$, and $D$ against the number of plant stems but did not differ markedly on the height of the plant, the number of leaves, ), fresh weight of plant stover and the fresh weight of the plant. Treatment A is more effective on plant height (23 $\mathrm{cm})$, ), fresh weight of plant stover $(7.31 \mathrm{gr})$, and fresh weight of plants $(6.38 \mathrm{gr})$. C treatment is more effective on the number of leaves (31.63 strands) and the number of stems (7.31 strands).

Keywords : Apium Graveolens L, Effectiveness, Liquid organic fertilizer, Rice laundry water 


\section{PENDAHULUAN}

Seledri (Apium graveolens L.) adalah jenis sayuran yang sangat popular saat ini terutama untuk kebutuhan seharihari, hal ini akan terus bertambah sejalan dengan bertambahnya jumlah penduduk serta kesadaran masyarakat akan pentingnya kebutuhan gizi seimbang, (Sukasih, 2017). Budidaya seledri tidak hanya pada kebun yang luas, tetapi pada lahan yang sempit seperti pada lahan perkarangan masih dapat diusahakan dalam pot atau polybag. (Dalimunthe \& Lestari, 2019). Seledri merupakan tanaman terbagi tangkai, umbi dan daun. Termasuk komoditas sayuran penyedap dan penghias hidangan. Biji seledri digunakan sebagai bumbu, penyedap dan ekstrak minyak bijinya berkhasiat untuk obat, (Balitsa, 2011). Seledri dapat menurunkan hipertensi dan pembersih hati dari racun yang merusak jaringan hati, (Surtinah et al., 2018).

Penggunaan pupuk kimia yang berlebihan menyebabkan kerusakan tanah dalam jangka waktu yang lama, (Paulina et al., 2020). Dengan semakin menurunnya kesuburan tanah, rusaknya sifat fisik dan kimia tanah, rendahnya daya ikat terhadap air hujan dan menurunnya persediaan bahan organik dalam tanah, (Sukasih, 2017). Penggunaan pupuk kimia dapat mengganggu kesehatan tubuh manusia dan lingkungan. Alternatif pupuk yang aman bagi kesehatan perlu dicari, (Wardiah et al., 2014).

Air cucian beras sering kali dibuang begitu saja karena dianggap limbah ketika memasak nasi padahal air cucian beras dapat dimanfaatkan dan memiliki potensi sebagai bahan pupuk organik cair, (Jumawati \& Paulina, 2020). Air cucian beras adalah salah satu limbah rumah tangga, dapat dimanfaatkan sebagai pupuk cair untuk memenuhi kebutuhan unsur hara tanaman, (Himayana \& Aini, 2018).
Komposisi kimia terkandung dalam air cucian beras adalah karbohidrat 41,3 g, protein $26,6 \mathrm{~g}$, lemak $18,3 \mathrm{~g}$, fosfor $0,029 \mathrm{~g}$, kalsium 0,019 g, besi 0,004 g, dan vitamin B 0,0002 g, (Paulina et al., 2020). Pati beras mengandung $0,8 \% \mathrm{~N}$, $0,29 \% \quad \mathrm{P}_{2} \mathrm{O}_{5}, 0,07 \% \quad \mathrm{~K}_{2} \mathrm{O}, 1,48 \% \mathrm{CaO}$, $1,14 \% \mathrm{MgO}, 10,04 \% \mathrm{C}$ - organik dengan $\mathrm{C} / \mathrm{N}$ sebesar 13, (Ariyanti et al., 2017).

Pemberian air cucian beras pada konsentrasi $100 \%$ memberikan pengaruh terhadap tinggi tanaman dan jumlah daun tanaman pare, (Novi \& Rizki, 2015). Berbagai konsentrasi air cucian beras terhadap tinggi tanaman pakchoy pada (umur 10 dan 20 HST) dan berat kering, (Wardiah et al., 2014). Permberian air cucian beras pada interval waktu 6 hari sekali menunjukkan nilai yang lebih baik pada tanaman selada, (Jumawati \& Paulina, 2020). Himayana \& Aini (2018) perlakuan $100 \%$ konsentrasi air cucian beras menghasilkan diameter tangkai tanaman semua umur pengamatan, bobot segar total tanaman dan bobot kering tanaman umur pengamatan 18 dan 30 HST lebih tinggi.

Pemberian $500 \mathrm{ml}$ air cucian beras yang diberikan 3 hari sekali menghasilkan pertambahan tinggi tanaman dan pertambahan lilit batang yang paling baik pada bibit karet klon GT1, (Ariyanti et al., 2018). Pertumbuhan tanaman sawi hijau terbaik diperoleh pada perlakuan air cucian beras fermentasi 15 hari konsentrasi 100\%, (Fadilah et al., 2019). Penambahan gula pasir sebanyak $40 \mathrm{gr}$ pada pengomposan sampah sayuran di Pasar Jati Banyumanik berpengaruh signifikan terhadap waktu pengomposan dan memiliki rasio $\mathrm{C} / \mathrm{N}$ sebesar 12,086\%, (Hadiwidodo et al., 2019). Tujuan penelitian untuk mendapatkan efektivitas terbaik dari pengaplikasian pemberian air cucian beras dan gula yang diperbanyak dengan air bersih 
terhadap pertumbuhan dan produksi tanaman seledri.

\section{METODE PENELITIAN}

\subsection{Tempat dan Waktu}

Penelitian di los bayangan Kebun

Percobaan Lempake/Kebun

Percobaan BPTP Kaltim di

Kelurahan Gunung Lingai,

Kecamatan Sungai Pinang, Kota

Samarinda. Pada bulan April sampai

Juni 2021.
Bahan menggunakan benih seledri varietas amigo, polybag, tanah, pupuk kandang, arang sekam, kapur, pestisida nabati, air cucian beras, air bersih dan gula pasir.

\subsection{Rancngan Penelitian}

Penelitian menggunakan Rancangan Acak Lengkap satu faktor dengan 4 perlakuan dan 4 ulangan, setiap ulangan terdapat 4 polybag sampel tanaman dan berjumlah 64 polybag tanaman. Perlakuan dan komposisi bahan disajikan pada tabel 1 .

\subsection{Bahan}

Tabel 1. Perlakuan dan Komposisi Bahan

\begin{tabular}{cl}
\hline Kode & \multicolumn{1}{c}{ Komposisi Perlakuan } \\
\hline & \\
\hline A & 1 liter air cucian beras +1 liter air bersih \\
B & 1 liter air cucian beras +2 liter air bersih \\
C & 1 liter air cucian beras beras +1 liter air bersih +2 gr gula pasir \\
D & 1 liter air cucian beras +2 liter air bersih +2 gr gula pasir. \\
\hline
\end{tabular}

Sumber: data terolah 2021

Prosedur penelitian: 1) media semai; campuran dari tanah, pasir dan pupuk kandang, 2) perlakuan benih dengan merendam air hangat benih seledri varietas Amigo, 3) penyemaian benih seledri di bak persemaian selama 60 hari, 4) media tanam; campuran dari tanah, pupuk kandang sapi, arang sekam dan kapur sebanyak $5 \mathrm{~kg}$ dimasukan ke polybag berukuran $30 \times 30 \mathrm{~cm}$ dan ditempatkan dilos bayangan secara acak, 5) penanaman 1 rumpun bibit seledri setiap polybag dan dilakukan sore hari, 6) pengaplikasian air cucian beras tiap 2 hari sekali sebanyak $100 \mathrm{ml} / \mathrm{tan}, 7$ ) pemeliharaan; penyiangan, pembumbunan, pengendalian hama dan penyakit menggunakan pesnab, 6) panen umur 6 MST.
Pengambilan data dilakukan umur 6 MST dan parameter yang diamati: tinggi tanaman $(\mathrm{cm})$, jumlah daun (helai), jumlah batang (helai), bobot segar brangkasan tanaman (gr) dan bobot segar tanaman (gr). Data hasil pengamatan dianalisis dengan one-way MANOVA menggunakan SPSS dan dilanjutkan dengan Tukey.

\section{HASIL DAN PEMBAHASAN}

\subsection{Hasil}

Hasil analisis data statistik pelaksanaan penelitian umur 6 MST menggunakan air cucian beras dan gula pasir yang diperbanyak dengan air bersih terhadap pertumbuhan dan produksi tanaman seledri (Apium Graveolens L.), disajikan pada Tabel 2 dan Gambar 1 dibawah ini: 
Tabel 2. Rerata Tinggi Tanaman, Jumlah Daun, Jumlah Batang, Bobot Segar Brangkasan dan Bobot Segar Tanaman Seledri Umur 6 MST

\begin{tabular}{lcccc}
\hline \multirow{2}{*}{ Parameter Pengamatan } & \multicolumn{3}{c}{ Perlakuan } \\
\cline { 2 - 5 } & A & B & C & D \\
\cline { 2 - 5 } & $23,00^{\text {tn }}$ & $18,85^{\text {tn }}$ & $20,42^{\text {tn }}$ & $19,31^{\text {tn }}$ \\
Tinggi tanaman (cm) & $31,50^{\text {tn }}$ & $21,25^{\text {tn }}$ & $31,63^{\text {tn }}$ & $23,13^{\text {tn }}$ \\
Jumlah daun (helai) & $7,19^{*}$ & $4,62^{*}$ & $7,31^{*}$ & $5,56^{*}$ \\
Jumlah batang (helai) & $7,31^{\text {tn }}$ & $4,08^{\text {tn }}$ & $6,25^{\text {tn }}$ & $4,33^{\text {tn }}$ \\
Bobot segar brangkasan tanaman (gr) & $6,38^{\text {tn }}$ & $3,59^{\text {tn }}$ & $5,45^{\text {tn }}$ & $3,82^{\text {tn }}$ \\
\hline
\end{tabular}

Tukey 0,05

Sumber : data terolah 2021

Keterangan $:$ tn $=$ beda tidak nyata pada taraf 0,05

$:^{*}=$ beda nyata pada taraf 0,05

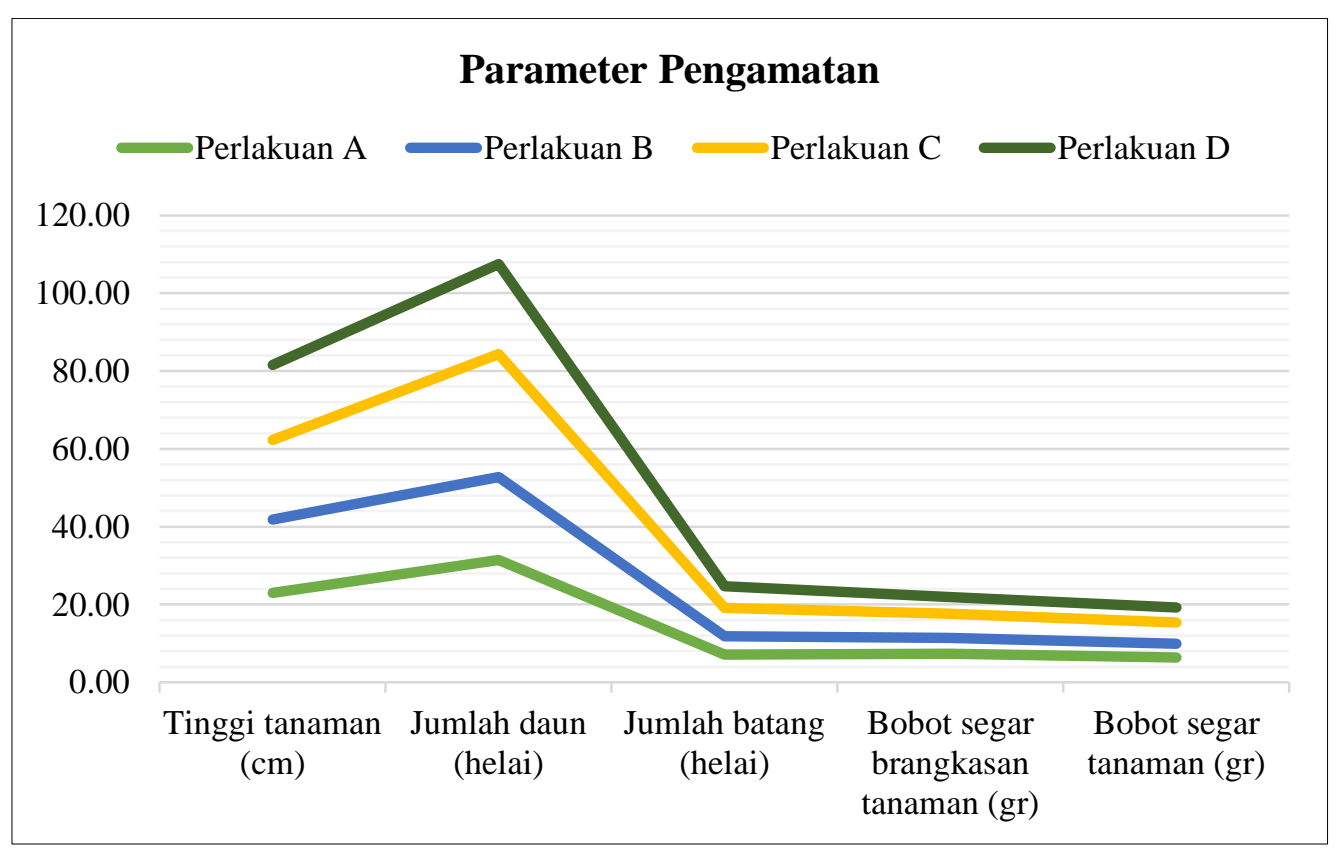

Gambar 1. Rerata Tinggi Tanaman, Jumlah Daun, Jumlah Batang, Bobot Segar Brangkasan Dan Bobot Segar Tanaman Seledri Umur 6 MST

Pemberian 1 liter air cucian beras +1 liter air bersih pada perlakuan A lebih efektif dari perlakuan B, C dan D dengan menunjukkan rerata tertinggi terhadap tinggi tanaman seledri yaitu 23 $\mathrm{cm}$. Hasil uji lanjut Tukey 0,05 terhadap tinggi tanaman seledri umur 6 MST pada 
perlakuan $\mathrm{A}, \mathrm{B}, \mathrm{C}$ dan $\mathrm{D}$ tidak berbeda nyata secara signifikan.

Pemberian 1 liter air cucian beras beras +1 liter air bersih +2 gr gula pasir pada perlakuan $\mathrm{C}$ lebih efektif dari perlakuan A, B dan $\mathrm{D}$ dengan menunjukkan rerata jumlah daun terbanyak pada tanaman seledri yaitu 31,63 helai. Hasil uji lanjut Tukey 0,05 terhadap jumlah daun seledri umur 6 MST pada perlakuan A, B, C dan D tidak berbeda nyata secara signifikan.

Pemberian 1 liter air cucian beras beras +1 liter air bersih +2 gr gula pasir pada perlakuan $\mathrm{C}$ lebih efektif dari perlakuan A, B dan $\mathrm{D}$ dengan menunjukkan rerata tertinggi terhadap jumlah batang tanaman seledri yaitu 7,31 helai. Hasil uji lanjut Tukey 0,05 terhadap jumlah batang tanaman seledri umur 6 MST pada perlakuan A, B, C dan $\mathrm{D}$ berbeda nyata secara signifikan.

Pemberian 1 liter air cucian beras +1 liter air bersih pada perlakuan A lebih efektif dari perlakuan B, C dan D dengan menunjukkan rerata tertinggi terhadap bobot segar brangkasan tanaman seledri yaitu 7,31 gr. Hasil uji lanjut Tukey 0,05 terhadap bobot segar brangkasan tanaman seledri umur 6 MST pada perlakuan A, B, C dan D tidak berbeda nyata secara signifikan.

Pemberian 1 liter air cucian beras + 1 liter air bersih pada perlakuan A lebih efektif dari perlakuan B, C dan D dengan menunjukkan rerata tertinggi terhadap bobot segar panen tanaman seledri yaitu 6,38 gr. Hasil uji lanjut Tukey 0,05 terhadap bobot segar panen tanaman seledri umur 6 MST pada perlakuan A, B, C dan D tidak berbeda nyata secara signifikan.

\subsection{Pembahasan}

Air cucian beras berpotensi untuk digunakan sebagai pupuk pada tanaman khususnya pada tanaman seledri namun pada konsentrasi yang rendah. Pada konsentrasi yang tinggi dapat diberikan setelah dilakukan pengenceran, (Lalla, 2018). Air cucian beras merupakan air yang berasal dari limbah rumah tangga yang sudah mengalami proses pengendapan yang biasanya tidak termanfaatkan, (Paulina et al., 2020).

Beberapa hasil penelitian pemberian air cucian beras yang telah dicobakan pada berbagai jenis tanaman. Hasil penelitian Purniawati et al., (2015) pemberian air kelapa dan air cucian beras pada pertumbuhan bibit karet (Hevea brasiliensis) stum mata tidur menunjukkan bahwa kombinasi interval dan air kelapa 9 hari dan dosis air beras 1,25 1/tanaman memberikan hasil terbaik untuk diameter batang, jumlah daun dan lebar daun. Baning et al., (2016), pengaruh pemberian air cucian beras merah memberikan pengaruh nyata $(\mathrm{P}>0,05)$ terhadap pertumbuhan vegetatif lada. jumlah daun umur 15 HST tertinggi terdapat pada perlakuan dengan konsentrasi $400 \mathrm{ml} / \mathrm{l}$ (P4), jumlah daun umur 30 HST tertinggi terdapat pada perlakuan dengan konsentrasi $400 \mathrm{ml} / \mathrm{l}$ (P4)), berat basah tanaman tertinggi terdapat pada perlakuan dengan konsentrasi $0,4 \mathrm{ppm}$ atau $400 \mathrm{ml} / \mathrm{l}(\mathrm{P} 4)$ dan berat kering tanaman tertinggi terdapat pada perlakuan dengan konsentrasi $400 \mathrm{ml} / \mathrm{l}(\mathrm{P} 4)$. Yulianingsih (2017), air cucian beras berpengaruh nyata terhadap hasil terung ungu, ditunjukkan oleh meningkatnya berat buah dengan hasil tertinggi pada perlakuan a5=1000 $\mathrm{ml}$ dengan rerata beratnya 69.17 gram/tanaman. Lalla (2018), pemberian air cucian beras pada perlakuan A3 (air cucian beras bilasan ketiga) menghasilkan jumlah daun yang lebih banyak dibanding perlakuan lainnya. Air cucian beras berpotensi untuk digunakan pada tanaman seledri namun pada konsentrasi yang lebih encer (air cucian beras bilasan ketiga). Sitohang et al., (2018) pemberian 
campuran nanas, air cucian beras dan gula dengan $\mathrm{C} / \mathrm{N}$ rasio 15 berpengaruh terhadap pertumbuhan bobot ikan lele, kelangsungan hidup dan efisiensi pakan tertinggi selama pemeliharaan. Fadilah et al., (2019), penyiraman air cucian beras fermentasi 15 hari konsentrasi 100\% berpengaruh meningkatkan tinggi tanaman, jumlah daun, luas daun, berat segar tanaman, dan berat kering tanaman sawi hijau. Paulina et al., (2020), pemberian bilasan air cucian beras pada perlakuan $\mathrm{C}_{3}$ memiliki nilai yang paling besar untuk seluruh pengamatan dibandingkan dengan perlakuan kontrol, $\mathrm{C}_{1}$, atau pun $\mathrm{C}_{2}$ pada tanaman pakcoy.

\section{KESIMPULAN}

Hasil penelitian efektivitas pemberian air cucian beras dan gula pasir yang diperbanyak dengan air bersih berbeda nyata pada perlakuan A, B, C dan $\mathrm{D}$ terhadap jumlah batang tanaman tetapi tidak berbeda nyata pada tinggi tanaman, jumlah daun, bobot segar brangkasan dan bobot segar tanaman. Perlakuan A lebih efektif pada tinggi tanaman $(23 \mathrm{~cm})$, bobot segar brangkasan (7,31 gr) dan bobot segar tanaman (6,38 gr). Perlakuan C lebih efektif pada jumlah daun (31,63 helai) dan jumlah batang (7,31 helai).

\section{UCAPAN TERIMA KASIH}

Penulis mengucapkan terima kasih kepada Saud Edo Manurung, Rujiansyah dan Absan yang berada di Kebun Percobaan Lempake yang sudah banyak membantu pikiran, tenaga dan saran sehingga pelaksanan penelitian ini bisa berjalan dengan lancar.

\section{DAFTAR PUSTAKA}

Ariyanti, M., Suherman, C., Anjarsari, I. R. D., \& Sartika, D. (2017). Respon Pertumbuhan Bibit Nilam Aceh
(Pogostemon cablin benth.) Klon Sidikalang Pada Media Tanam Subsoil Dengan Pemberian Pati Beras dan Pupuk Hayati. Jurnal Kultivasi, 16(3), 394-401. https://doi.org/10.24198/kltv.v16i3. 14429

Ariyanti, M., Suherman, C., Rosniawaty, S., \& Franscyscus, A. (2018). Pengaruh Volume dan Frekuensi Pemberian Air Cucian Beras Terhadap Pertumbuhan Bibit Tanaman Karet (Hevea brasiliensis Muell.) Klon GT 1. Paspalum: Jurnal Ilmiah Pertanian, 6(2), 114 123.

https://journal.unwim.ac.id/index.p hp/paspalum/article/download/94/7 8

Balitsa. (2011). Petunjuk Teknis Budidaya Seledri. Balai Penelitian Tanaman Sayuran, 1-2. http://hortikultura.litbang.pertanian. go.id/leaflet/JuknisSeledri.pdf

Baning, C., Rahmata, H., \& Supriatno. (2016). Pengaruh pemberian air cucian beras merah terhadap pertumbuhan vegetatif tanaman lada (Piper nigrum L.). Jurnal Ilmiah Mahasiswa Pendidikan Biologi, 1(1), 1-9.

Dalimunthe, B. A., \& Lestari, W. (2019). Pengaruh Aplikasi Pupuk NPK Terhadap Pertumbuhan dan Hasil Tanaman Seledri (Apium graveolens L.). Jurnal Agroplasma, 6(2), 23-28.

Fadilah, A. N., Darmanti, S., \& Haryanti, S. (2019). Pengaruh Penyiraman Air Cucian Beras Fermentasi Satu Hari Dan Fermentasi Lima Belas Hari Terhadap Kadar Pigmen Fotosintetik Dan Pertumbuhan Vegetatif Tanaman Sawi Hijau (Brassica juncea L.). Jurnal Bioma, 
2l(1), 47-54.

Hadiwidodo, M., Sutrisno, E., \& Sabrina, A. (2019). Pengaruh Variasi Gula Pasir Terhadap Waktu Pengomposan Ditinjau Dari Rasio C/N Pada Sampah Sayuran di Pasar Jati Banyumanik Dengan Penambahan Bioaktivator Lingkungan. Jurnal Presipitasi: Media Komunikasi Dan Pengembangan Teknik Lingkungan, 16(1), 36-43. https://doi.org/10.14710/presipitasi. v16i1.36-43

Himayana, A. T. S., \& Aini, N. (2018). pengaruh pemberian Air Limbah Cucian Beras terhadap Pertumbuhan Dan Hasil Tanaman Pakcoy (Brassica rapa var. chinensis). Jurnal Produksi Tanaman, 6(6), 1180-1188. http://protan.studentjournal.ub.ac.id /index.php/protan/article/download/ 763/786

Jumawati, R., \& Paulina, M. (2020). Respon Pertumbuhan dan Hasil Selada (Lactuca Sativa L.) Terhadap Interval Waktu Aplikasi Pemberian Air Cucian Beras. Jurnal Agroekoteknologi Dan Pertanian (JURAGAN), 1(1), 2532.

Lalla, M. (2018). Potensi Air Cucian Beras Sebagai Pupuk Organik pada Tanaman Seledri (Apium Graveolens L.). Journal Agropolitan, 5(1), 38-43.

Novi, \& Rizki. (2015). Pertumbuhan Vegetatif Tanaman Pare (Momordica charantia L.) Yang diberi Air Cucian Beras Pada Berbagai Konsentrasi. Jurnal BioCONCETTA, 1(2), 67-73. http://ejournal.stkip-pgrisumbar.ac.id/index.php/BioCONCE TTA
Paulina, M., Lumbantoruan, S. M., \& Septiani, A. (2020). Potensi Pemanfaatan Limbah Air Cucian Beras Pada Tanaman Pakcoy (Brassica Rapa L.). Jurnal Agroteknologi Dan Pertanian (JURAGAN), 1(1), 17-24.

Purniawati, D. I., Sampurno, \& Armaini. (2015). Pemberian Air Kelapa Muda dan Air Cucian Beras Pada Bibit Karet (Hevea brasiliensis) Stum Mata Tidur. Jurnal JOM Faperta, 2(1), 1-10. https://doi.org/10.3969/j.issn.10080813.2015.03.002

Sitohang, M. L., Fitrani, M., \& Jubaedah, D. (2018). Pemanfaatan Campuran Buah Nanas, Air Cucian Beras dan Gula Sebagai Sumber Karbon Pada Media Pemeliharaan Ikan Lele (Clarias sp) Dengan Sistem Bioflok. Jurnal Akuakultur Rawa Indonesia, 6(1), 51-64. https://doi.org/10.36706/jari.v6i1.7 149

Sukasih, L. S. (2017). Pengaruh Pupuk Hayati Evagrow Terhadap Pertumbuhan Dan Hasil tanaman Seledri (Apium graveolens L.). Jurnal Piper, 13(25), 139-147. https://doi.org/10.7868/s0032180x1 7120024

Surtinah, Susi, N., \& Endriani. (2018). meningkatkan Daya Berkecambah Benih Seledri (Apium Graviolens) Dengan Invigorasi. Jurnal Bibiet, $3(1)$, 33-39. https://doi.org/10.22216/jbbt.v2i2.3 342

Wardiah, Linda, \& Rahmatan, H. (2014). Potensi Limbah Air Cucian Beras Sebagai Pupuk Organik Cair Pada Pertumbuhan Pakchoy (Brassica rapa L.). Jurnal Biologi Edukasi Edisi 12, 6(1), 34-38. http://jurnal.unsyiah.ac.id/JBE/articl 
e/download/2274/2865

Yulianingsih, R. (2017). Pengaruh Air Cucian Beras Terhadap Pertumbuhan Dan Hasil Terung Ungu (Solanum Melongena L.). Jurnal Piper, 13(24), 61-68. http://jurnal.unka.ac.id/index.php/pi per/article/download/68/158 